\title{
SKRYPTORIA KLASZTORNE I ŚREDNIOWIECZNE USTAWODAWSTWO CYSTERSKIE O KSIĄŻCE
}

Do cywilizacyjnego i kulturowego dorobku wczesnopolskiej przeszłości od drugiej połowy X do pierwszej połowy XIII stulecia doszły nowe, ważne elementy związane zarówno z kulturą materialną i umysłową, tworzącym się systemem edukacji przykatedralnej, klasztornej, skryptoriami i nade wszystko książką. Najstarsze księgi, jakie znalazły sią na ziemiach wczesnopiastowskich w drugiej połowie X w., łączy się ze skryptoriami benedyktyńskich klasztorów z terenu Bawarii, Saksonii, Nadrenii czy Lotaryngii. Pierwsze księgi rękopiśmienne to kodeksy z tekstami biblijnymi oraz księgi liturgiczne niezbędne do sprawowania Mszy św., które wraz z paramentami kościelnymi sprowadzano do tworzących się ośrodków nowo przyjętego kultu. Były to Ewangeliarze związane z celebrą mszalną, od początku otaczane dużym szacunkiem jako literalne ucieleśnienie Słowa Bożego, a także Ewangelistaria (zwane perykopami), zawierające fragmenty tekstu Ewangelii ułożone w porządku roku kościelnego.

W kulturze książki rękopiśmiennej w średniowieczu ogromną rolę obok benedyktynów odegrali cystersi sprowadzeni do Polski w latach czterdziestych XII stulecia i osadzeni w małopolskim Jędrzejowie. Z biegiem czasu w 26 opactwach cysterskich powstałych na przestrzeni od połowy XII do pierwszej połowy XIV stulecia działalność piśmiennicza w przyklasztornych skryptoriach była ważnym elementem rozwoju życia zakonnego. Przepisywanie, kopiowanie oraz iluminowanie kodeksów rękopiśmiennych we wczesnym i rozwiniętym średniowieczu było obowiązkiem i swoistym modus vitae zakonników reguły benedyktyńskiej. Regula Sancti Benedicti to podstawowy i zarazem najważniejszy zbiór przepisów prawa zakonnego regulujący życie zakonów benedyktyńskich, cystersów i kamedułów, i choć nie traktuje wprost o książce i bibliotece, jednakże poświęca jej sporo uwagi. Św. Benedykt z Nursji w tekście Reguły bardzo wyraźnie mówi o wyznaczonych dla mnichów godzinach lektur w czasie trwania Wielkiego Postu, a także o wypożyczaniu kodeksów z biblioteki w tym czasie ,[...] w dniach Wielkiego Postu od rana do końca godziny trzeciej niech czas poświęcą czytaniu, a następnie do końca godziny dziesiątej wykonują powierzona pracę. W tych dniach Postu każdy otrzyma z biblioteki jedną książkę, którą powinien przeczytać od pierwszej do ostatniej strony w całości. Książki te trzeba rozdać w okresie Wielkiego Postu [...] ${ }^{\mathrm{I}}$. Dalej w księdze 48 Reguły, zapisano, iż [...] w niedzielę natomiast niech czytaniem zajmują się wszyscy, oprócz tych, których wyznaczono do innych funkcji”’. Z tego zapisu dość jasno wynika, że św. Benedykt zakładał, iż w każdym

\footnotetext{
Św. Benedykt z Nursji, Reguła, przekł. A. Świderkówna, Kraków 1997, rozdz. 48, s. 177.

2 Tamże, s. 179.
} 
klasztorze musiało istnieć jakieś skryptorium i choćby najmniejsza biblioteka gromadząca kodeksy, bez której trudno sobie wyobrazić funkcjonowanie wspólnoty zakonnej. Zgodnie z zaleceniami św. Benedykta mnisi benedyktyńscy i cysterscy musieli poświęcać czas na lekturę w określonych porach dnia w ciągu całego roku. Pobożna lektura i wiążąca się z nią medytacja miały w rozumieniu św. Benedykta przede wszystkim zbliżyć mnichów do Boga, gdyż w rozumieniu Reguły jedynym celem życia monastycznego było poszukiwanie Boga we wszystkim. O książkach wspomina również najstarsze ustawodawstwo cysterskie. $\mathrm{Na}$ przestrzeni ponad dziewięciu wieków książka w życiu monastycznym cystersów odgrywała zawsze bardzo ważną rolę. Była niezbędna do realizowania przepisanej lectio Divina, z liturgią, modlitwą, ćwiczeniami duchowymi, poznawaniem Biblii i jej wykładem, studiowaniem Reguły, statutów, consuetudines, budowaniem duchowym i doskonaleniem duszy (czytanie martyrologium, vitae patrum, dzieł ascetycznych) czy głoszonymi kazaniami. Przepisy określające zasady zakładania nowych domów cysterskich zobowiązywały opactwo macierzyste, by mnichów wysyłanych do nowego coenobium zaopatrzyło przynajmniej w dziewięć podstawowych i niezbędnych zarazem ksiąg: mszał, Regułę, Liber usuum, psałterz, hymnariusz, kolektarz, lekcjonarz, antyfonarz i graduał: ,[...] duodecim monachii cum abbate terciodecimo ad coenobia nova transimittantur: nec tamen illuc destinentur donec locus libris domibus et necessariis apretur, libris dumtaxit missali, Regula, libro usuum, psalterio, hymnario, collectane, lectionario, anthiphonario, gradali, regula, missali [...]"3.

Za najbardziej niezbędne w początkowym okresie funkcjonowania każdego opactwa jako samodzielnej jednostki uznano także księgi regulujące życie klasztorne, były to Reguła oraz Liber usuum, a także kodeksy liturgiczne niezbędne do sprawowania codziennej liturgii. Z czasem liczba ksiąg została ograniczona do siedmiu: psałterza, hymnariusza, kolektarza, graduału, antyfonarza, Reguły i mszału: ,[...] de construendis abbatiis: Non mittendum esse abbatem novum in locum novellum sine monachis ad minus XII-cim, nec sine libris istis: psalterio, hymnario, collectane, antiphonario, gradali, regula, missali [...]"4.

Prawodawcy cysterscy określali dość jednoznacznie zbiór podstawowych ksiąg, który powinien znaleźć się w każdym klasztorze. Należał do nich: mszał, epistolarz, ewangeliarz, kolektarz, graduał, antyfonarz, hymnariusz, psałterz, lekcjonarz i kalendarz ${ }^{5}$. Z czasem zaczęto gromadzić księgi niezbędne do pogłębiania życia duchowego i intelektualnego mnichów cysterskich. Z tego też okresu pochodzą przepisy dotyczące przepisywania, kopiowania i iluminowania ksiąg w skryptoriach klasztornych. Ustawodawca cysterski dość jednoznacznie i surowo określał zasady, kto mógł podjąć się tego ważnego zadania. Otóż w jednym z punktów zapisano, że ani zakonnikowi, ani nowicjuszowi, ani tym bardziej opatowi nie wolno pisać (tworzyć) ksiąg, wyłączone było od tego zakazu kopiowanie, chyba że czynność ta odbywała się za przyzwoleniem Kapituły Generalnej: ,„[...] nulli licea abbati nec monacho nec novotio libros facere, nisi forte cuiquam id in generali abbatum capitulo concessum fuerit"'.

\footnotetext{
Statuta Capitulorum generalium ordinis Cisterciensis ab anno 1116 ad annum 1786, wyd. J.M. Canivez, t.1, Louvain 1933-1941, nr 12, s. 15.

4 Tamże, t. 1, nr 9, s. 12.

E. Potkowski, Kultura piśmienna cystersów, w: Pelplin. 725 rocznica powstania opactwa cysterskiego. Kulturotwórcza rola cystersów na Kociewiu, red. D.A. Dekański, Pelplin-Tczew 2002, s. 87-89.

6 Statuta Capitulorum generalium ordinis Cisterciensis ab anno 1116 ad annum 1786, wyd. J.M. Canivez, t.1, nr 58, s. 26.
} 
Takie poglądy wyrażał także św. Bernard z Clairvaux w jednym z najwcześniejszych swoich dzieł, Apologia ad Guilelmum. Według obowiązującego prawa cysterskiego, a nade wszystko poglądów głoszonych przez św. Bernarda, wielkiego orędownika skromnej sztuki cysterskiej, ksiąg nie wolno było zdobić, a ich oprawy zamykać za pomocą srebrnych, złotych czy pozłacanych klamer. Podobne postanowienia dotyczyły zdobienia kart kodeksów, które uważano za zbyteczne i rozpraszające uwagę modlącego się mnicha cysterskiego. Według św. Bernarda idea piękna zawartego w prostocie wyrażała się w stwierdzeniu, że piękno wewnętrzne jest wspanialsze od wszelkiej ozdoby zewnętrznej, a piękno zmysłowe nie jest samo w sobie złe, ale następuje tylko wówczas, gdy objawia się w nim duch ${ }^{7}$. Zachowane akta kapituł generalnych zakonu cystersów stanowiły, że skryptoria mają być urządzone prosto, bez zbytku, a w czasie pracy nad tekstem powinna panować cisza: ,[...] in omnibus scriptoriis ubicumque ex consuetudine monachi scribunt, silentium teneatur sicut in claustro [...]" , ponadto, że poza określonymi godzinami, pisarze mają ksiąg nie przepisywać ani ich nie czytać: ,[...] scriptores extra terminos non scribant, non libros legunt, ne hostiae fiant [... ]"9. Pod koniec średniowiecza cysterscy mnisi w ramach lectio divina byli zobowiązani do czytania lub wysłuchiwania przeciętnie nawet do 50 tomów tekstu po około 300 stronic rocznie. Takie rozporządzenia sprawiały, że szczególnego znaczenia nabierała praca kopisty $^{10}$. Mnichów cysterskich zobowiązywano do pobożnej lektury i studiowania Pisma Świętego, dzieł patrystycznych, ksiąg hymnów i ksiąg zwyczajów (libri usuum) niezbędnych dla rejestracji wszelkich zmian dotyczących reguły i liturgii. O znaczeniu pracy skryptorów w klasztorach cysterskich świadczą miedzy innymi zwalnianie ich przez Kapitułę Generalną zakonu od innych obowiązków na rzecz klasztoru, a także dopuszczenie w niektórych przypadkach do pracy w porze nakazanej na wypoczynek. Doskonale widoczne jest to na przykładzie klasztoru w Himmerod w Nadrenii, gdzie pochylano się nad przepisywanym mozolnie tekstem w porze nocnej, w której reszta konwentu zobowiązana była do snu ${ }^{\mathrm{II}}$.

Traktaty i księgi w życiu zakonu stawały się nieodłącznym atrybutem w codziennej realizacji dewizy św. Benedykta z Nursji - módl się i pracuj. W powstających na ziemiach polskich opactwach cysterskich niezależnie od ich wielkości, położenia, osoby fundatora i uposażenia organizowano skryptoria, a z czasem biblioteki. Jak już zaznaczono, do podstawowych sposobów tworzenia księgozbiorów cysterskich należało w początkowym stadium istnienia każdego opactwa wyposażenie go w księgi liturgiczne otrzymane od macierzystego klasztoru. Ich liczba i rodzaj były skrupulatnie wyliczone ${ }^{\mathrm{I} 2}$. Wspomniane statuty kapituły generalnej cystersów z II34 r. postanawiały: „Dwunastu mnichów z trzynastym opatem mogą przejść do nowego klasztoru, nie mogą tam jednak zostać zatwierdzeni dopóki nie zostanie przygotowane miejsce dla ksiąg, mieszkań i niezbędnych rzeczy, przynajmniej dla ksiąg

\footnotetext{
7 L. Wetesko, Średniowieczna architektura i sztuka w kręgu zakonu cystersów, w: Monasticon Cisterciense poloniae, t. 1, red. A.M. Wyrwa, J. Strzelczyk, K. Kaczmarek, Poznań 1999, s. 216 - 217.

8 Canivez, Statuta Capitulorum generalium ordinis Cisterciensis ab anno 1116 ad annum 1786, wyd. J.M. Canivez, t. 1 , nr 85, s. 32 .

9 Tamże, t. 1, nr 31, s. 58.

10 Tamże. Zob. też: A. Schneider, Skriptorium und Bibliothek der Cistercienser abtei Himmerod in Rheinland zur Geschichte klosterlichen Bibliothekswesens im Mittelalter, „Bulletin of the John Rylands Library”, 35/1952, nr 1, s. 155 .

11 Tamże.

12 T. Manteuffel, Rola cystersów w Polsce w wieku XII, „Przegląd Historyczny”, 41/1950, s. 181; H. Szwejkowska, Biblioteka klasztoru cysterek w Trzebnicy, Wrocław 1955, s. 37-38.
} 
mszalnych, reguły, ksiąg ćwiczeń, psałterza, hymnarza, kolekcjonarza, dormitorium, celi gościnnej i furtiana oraz rzeczy niezbędnych do życia doczesnego, tak, aby można tam żyć i natychmiast zachować regułę"’3. Punkt 85 wspomnianej Kapituły Generalnej regulował zasady powstawania i organizacji skryptoriów w poszczególnych opactwach filialnych, tak by były one niezależne w kopiowaniu ksiąg od klasztoru macierzystego ${ }^{14}$. Z kolei pochodzący z I2I2 r. I7 statut Kapituły Generalnej cystersów zalecał mnichom, by posiadali na stanie swojego opactwa co najmniej 9 kodeksów. Miały to być księgi liturgiczne takie jak: mszał, graduał, psałterz, hymnariusz, lekcjonarz, antyfonarz oraz kalendarz, reguła zakonna i konstytucje. Dalszy rozwój biblioteki zależał w dużej mierze od tego, czy klasztor posiadał własne skryptorium, które wytwarzało kodeksy na potrzeby opactwa, te zaś były konieczne przy prowadzeniu studiów oraz pogłębianiu wiedzy teologicznej i filozoficznej.

Ponadto rozporządzenia kapituł cysterskich zalecały, by wyodrębnić z armarium klasztornego księgi prawnicze, np. Corpus canonum i Decretum Gratiani, ponieważ jak zapisano, ich obecność we wspólnym armarium mogłaby doprowadzić do tego, że mnisi byliby wprowadzeni w błąd, gdyż zawierały sprzeczne ze sobą kanony, które jedynie kompetentna i biegła w prawie osoba mogła zrozumieć i właściwie zinterpretować. Pozostawienie Decretum Gratiani i Corpus canonum poza wspólnym armarium było poniekąd działaniem prewencyjnym, które ograniczało do minimum błędne interpretacje i nieuzasadnione spory pomiędzy nieobeznanymi w prawie mnichami cysterskimi: ,[...] liber qui dicitur Corpus canonum et Decreta Gratiani apud eos qui habuerint secretius custodiantur, ut cum opus fuerit proferantur. In communi armario non resident, propter varios qui inde possunt provenire errores, dalej: Liber qui dicitur Corpus canonum et decreta Gratiani in communi armario non ponantur"'5. Był to swoisty zakaz do sięgania po księgi, których błędna interpretacja mogłaby być przyczyną chaosu wewnętrznego za murami klauzury. Po upływie kilku wieków taki zakaz będzie dotyczył ksiąg niezgodnych (tzw. prohibita) z uznawaną doktryną Kościoła katolickiego.

W dużych klasztorach benedyktyńskich i cysterskich wydzielano specjalne pomieszczenie przeznaczone całkowicie na potrzeby „warsztatu”, gdzie przepisywano rękopisy, zwyczajowo określano to miejsce jako scriptorium. W pomieszczeniu znajdowały się pulpity przystosowane do kopiowania tekstów, z czasem przytwierdzano do nich łańcuchy, by chroniły przepisywane kodeksy przed kradzieżą. Przepisane kodeksy przechowywano w specjalnie do tego typu przeznaczonych szafach, tzw. armariach. Trzeba zaznaczyć, iż dla tych, którzy kopiowali i byli użytkownikami ksiąg, ważne było miejsce ich przechowywania. W klasztorze było to z reguły kilka wyznaczonych miejsc: właściwe skryptorium, a przy nim tworząca się biblioteka, zakrystia, skarbiec klasztorny, chór zakonny, cela opata, krużganki klasztorne i refektarz klasztorny. Do obowiązków klasztornego kopisty należało przygotowanie kart pergaminowych przeznaczonych do zapisania, podzielenia go in folio na kolumny, przygotowanie inkaustu oraz wszelkich narzędzi niezbędnych do pracy, były

\footnotetext{
13 Canivez, Statuta Capitulorum Ordinis Cisterciensis ab anno 1116 ad annum 1786, t. 1, nr 85, s. 12; J.M. Marszalska, Biblioteka opactwa cystersów w Szczyrzycu do końca XIX stulecia. Dziedzictwo wieków, Tarnów 2007, s. 13; A.M. Wyrwa, Rozprzestrzenianie się cystersów w Europie Zachodniej i na ziemiach polskich, w: Cystersi w kulturze średniowiecznej Europy, red. J. Strzelczyk, Poznań 1992, s. 27; S. Rybandt, Średniowieczne opactwo cystersów w Rudach, Wrocław 1977, s. 98.

14 K. Bobowski, Skryptorium dokumentowe klasztoru cystersów w Dargunie do końca XIII wieku, Wrocław 1991, s. 7-8.

15 Tamże, t. 1, nr 7, s. 108.
} 
nimi między innymi: rylec, pióro gęsie, trzcinka, pumeks. Trzeba zaznaczyć, że oprócz przepisywanych tekstów biblijnych, fragmentów dzieł ojców Kościoła, reguły życia zakonnego czy ksiąg liturgicznych w klasztornym scriptorium powstawały także dokumenty dotyczące fundacji klasztoru i jego uposażenia. Skryba, który zajmował się kopiowaniem manuskryptu, przygotowywał czystopis dokumentu z zachowaniem zasad dyplomatyki. Stawało się zatem scriptorium klasztorne miejscem, gdzie ars dictandi spotykała się z ars scribendi. We wczesnym średniowieczu - jak zauważył franciszkański teolog i filozof - św. Bonawentura - w komentarzu do Sentencji Piotra Lombarda, występowały cztery sposoby pisania, a tym samym cztery rodzaje pisarzy. Pierwszym był kopista (scriptor), którego głównym zadaniem było przepisywanie cudzych tekstów, do których nic nie mógł dodać i nic zmienić, drugim był kompilator (compilator) który przepisywał cudze teksty, dodając do nich inne teksty, trzecim był komentator (commentator) zwany też glosatorem, który przepisywał cudze teksty, ale dodawał także własne fragmenty w postaci uwag i komentarzy do przepisywanego tekstu, czwartym był autor (auctor) który pisał swoje teksty, a z cudzych czerpał tylko potwierdzenie dla własnych myśli ${ }^{16}$. Wszyscy wyżej wspomniani wpisywali się swoją pracą i umiejętnościami w rodzącą się kulturę słowa i tekstu pisanego w epoce średniowiecza europejskiego, a tym samym i polskiego.

Z biegiem czasu zarówno skryptorium klasztorne i wypełnione kodeksami armaria biblioteczne weszły na stałe do planu wyposażenia klasztorów mniszych, o czym świadczy znane ówczesne przysłowie łacińskie związane z klasztorem benedyktynów w Sankt Gallen: „Claustrum sine armario est quasi castrum sine armamentario”, (klasztor bez biblioteki jest jak twierdza bez zbrojowni) ${ }^{17}$. To celne określenie miało również swoje przełożenie na pierwsze kodeksy rękopiśmienne powstające w klasztorach benedyktyńskich i cysterskich na ziemiach polskich. Przepisywane traktaty teologiczne, teksty prawnicze, receptury medyczne, formuły prawnicze i sentencje filozoficzne były niezbędne w procesie średniowiecznego zdobywania wiedzy w szkołach przykatedralnych i klasztornych. Książka w takim procesie była niezbędna. Wiedzę o średniowiecznym świecie czerpano nie tylko dzięki kopiowaniu tekstów biblijnych i teologicznych, a te były za murami klasztorów niezbędne. Dopiero pierwsze roczniki, żywoty świętych czy kroniki stają się zalążkiem do szerszego poznania otaczającego świata.

Zawartość tematyczna pierwotnego księgozbioru klasztornego z reguły przedstawiała się następująco: na poczesnym miejscu była zawsze Biblia, jej konkordancje i komentarze, pisma ojców Kościoła, w oparciu o które poznawano dzieje Kościoła w pierwszych wiekach chrześcijaństwa, dalej teologia spekulatywna, ascetyka i mistyka, liturgika, teksty kaznodziejskie, hagiografia i żywotopisarstwo, które było w pewnym sensie zalążkiem historii Kościoła, niezbędna również w procesie kształcenia zakonnego filozofia, prawo kanoniczne i cywilne oraz teksty zawierające wiedzę z szeroko pojętych nauk przyrodniczo-medycznych (astronomia, astrologia, geometria). Treść kopiowanych ksiąg w klasztornych skryptoriach przybliżała człowieka do wiedzy, dzięki której mógł poznać otaczający go świat w całej złożoności zachodzących zjawisk i nieuchronnych przemian.

W skryptoriach cysterskich obok kopiowania tekstów liturgicznych, memoratywnych libri vivorum et mortuorum, redagowano także dokumenty będące wytworem bieżącej pracy

\footnotetext{
16 E. Potkowski, Pisarz i jego dzieło w średniowiecznym społeczeństwie, Warszawa 1997, s. 306-307.

17 K. Głombiowski, H. Szwejkowska, Książka i biblioteka w starożytności i średniowieczu, Warszawa 1979, S. $100-101$.
} 
administracyjno-gospodarczej klasztoru. W ciszy klasztornego skryptorium powstawały roczniki, nekrologi, kroniki klasztorne, czy dokumenty gospodarcze klasztoru związane z jego uposażeniem, wierszowane epitafia, nierzadko rozwijano oryginalną twórczość literacką i historiograficzną ${ }^{18}$. Zapisywano w nich wzmianki o codziennym życiu za murami klauzury, imiona i funkcje sprawowane przez braci zakonnych, szczególne wydarzenia dziejące się z dala od klasztoru, wzmianki o klęskach elementarnych nawiedzających najbliższą okolicę, szkody, jakie poniósł klasztor w wyniku powodzi, pożaru czy epidemii. Odnotowywano też odwiedziny co znamienitszych osób, książąt czy monarchów za murami klasztoru, słowem wszystko, co towarzyszyło mnichowi i było dla niego ważne w ciągu życia. Zachowane kroniki klasztorne są nieocenionym źródłem do poznania umysłowości, stosunków międzyludzkich panujących w małych wspólnotach zakonnych ich relacji z najbliższym otoczeniem i oceny otaczającej rzeczywistości średniowiecznego oglądu świata. Do takich dzieł należy między innymi unikalna pod każdym względem Liber fundationis claustri Sanctae Mariae Virginis in Henrichow - kronika klasztoru cystersów w Henrykowie na Śląsku (fund. I227), zwana w historiografii polskiej Księgą Henrykowską, a spisana przez opata Piotra po I268 r. Warto zaznaczyć, iż to właśnie w Księdze Henrykowskiej po raz pierwszy zostało zapisane pełne zdanie w języku polskim: „Day, ut ia pobrusa, a ti poziwai”. Tak jak w przypadku wielu kodeksów rękopiśmiennych powstających wówczas w skryptoriach klasztornych, pisarz, kopista czy iluminator z reguły pozostawał osobą anonimową, tak w przypadku dokumentów, jakimi są kroniki klasztorne „,autorstwo” często przez fakt podpisania fragmentów tekstu czy ustalenia rządów opackich w klasztorach monastycznych jest dosyć jednoznaczne. Trzeba też zauważyć, że wytwarzanie dokumentów (a do takich należały kroniki) miało charakter piśmienności pragmatycznej, nie dotykało więc sacrum, czyli Pisma Świętego wobec którego człowiek był zawsze anonimowy.

Często poszczególne fragmenty przepisywane były przez różnych kopistów, którzy nie zawsze podpisywali się na końcu dzieła. W tym miejscu warto zaznaczyć, iż żyjący na przełomie V/VI w. Magnus Aurelius Cassiodorus (Kasjodor), początkowo kanclerz króla Teodoryka Wielkiego, później mnich benedyktyński i założyciel jednego z najlepszych skryptoriów w klasztorze Vivarium w Kalabrii, w swoim dziele Institutiones podkreślał wielkie znaczenie samego aktu pisania, ale nie nalegał, by pisarz czy kopista zaznaczał swoje imię. Według Kasjodora ${ }^{19}$ pisarz przekazywał słowa Pisma Świętego, a piszący skryba klasztorny był tylko niegodnym czeladnikiem boskim, któremu nie uchodziło obok imienia Boga zamieszczać swoje własne. Podobnie i Alkuin (ok.730-804) ${ }^{20}$, chwaląc kopistów za staranne przepisywanie tekstów, przypominał, iż są oni jedynie narzędziem w ręku Boga, zaś Hraban Maur, opat benedyktynów w Fuldzie ${ }^{21}$, określił przepisywanie i kopiowanie ksiąg jako czynność świętą i sakralną, za którą nagroda będzie wyższa niż za wszystkie inne prace. Takich i podobnych w tonie wypowiedzi, będących świadectwem monastycznej kultury średniowiecza, doszukać się można w wielu pismach. ${ }^{22}$ Słowa Kasjodora i jemu współczesnych znane były w polskich

18 K. Bobowski, op. cit., s. 18-19.

19 K. Głombiowski, H. Szwejkowska, op. cit., s. 101-103.

20 Tamże.

21 Tamże.

22 Miłość nauki a pragnienie Boga, przekł. M. Borkowska, w: Źródła monastyczne. Opracowania, t. 14, red. J.A. Spież, Kraków 1997. 
opactwach benedyktyńskich i cysterskich, gdzie przez wieki w ciszy i skupieniu anonimowi kopiści pochylali się nad pulpitami pokrytymi pergaminem gotowym do zapisania. Warto na koniec zacytować fragment myśli znakomitego szwedzkiego historyka książki, Svenda Dahla, który w kilku słowach oddał istotę pracy w klasztornym skryptorium: „W cichej izbie kopistów, w skryptorium, dokąd nie dochodził zgiełk świata i gdzie życie ujęte było w surowe ramy reguł zakonnych, siedzieli mnisi lub mniszki, oddając swój trud ku chwale Boga. W wielu dawnych rękopisach zawarta jest praca długich lat i chyba niemożliwe byłoby dokonanie jej gdzie indziej poza klasztorami, gdzie życie płynęło „sub specie aeternitatis” [...]. Skryptoria zapełniali zazwyczaj młodzi mnisi i członkowie nowicjatu, znani są jednak także liczni duchowni i opaci, którzy byli gorliwymi kopistami. Często wielu braci pracowało nad jednym i tym samym kodeksem, każdy nad swoim wycinkiem i rozdziałem"²3.

\section{The scriptural monastery and medieval Cistercian legislation on the book Summary}

The oldest book which was on the territory of the early Piast in the second half of the tenth century derived, comes from the Benedictine scriptoria from the area of Bavaria, Saxony, Rhineland and Lorraine and contained the biblical texts and established liturgical canon necessary for the celebration of the Mass. Preserved from the twelfth century regulations of Cistercian chapters which decided that in each monastery there should be: missal, epistolary, Gospel Book, gradual, antiphonary, liber hymnarius, psaltery, lectionary and calendar. These regulations made the copywriter's work particularly important. The importance attributed to their work is attested to, for example, by their release by the General Chapter of the Order from other duties in favor of the monastery, and by the permission in some cases to work at night. In Cistercian scriptoria apart from copying of the liturgical texts, the memorials so-called libri virorum et mortuorum, there were preparing documents for the current administrative and economic work of the monastery; in addition there were writing yearbooks, obituaries, monastery chronicles or epitaphs poem. There were recording notes of daily life outside the walls of the enclosure, names and functions of friars particularly events that took place away from the monastery or notes about elementary disasters happening in the proximate areas, the damages of monastery caused by floods, fires or epidemics. The preserved manuscript codes are an priceless source for learning the minds, interpersonal relationships prevailing in the small communities, their relations with their nearest surrounding and medieval way of seeing the world.

Keywords: monastery, scriptorium, manuscript code, Benedict, Cistercian

Nota o Autorze: Prof. zw. dr hab. Jolanta M. Marszalska - profesor zwyczajny w Instytucie Nauk Historycznych Wydziału Nauk Historycznych i Społecznych Uniwersytetu Kardynała Stefana Wyszyńskiego w Warszawie. Prowadzi badania nad staropolska kulturą piśmiennictwa, monastycyzmem, księgozbiorami klasztornymi: benedyktynów, cystersów, bernardynów i karmelitów bosych, historycznymi księgozbiorami diecezji tarnowskiej i płockiej oraz księgozbiorami i dziejami rodów magnackich.

23 S. Dahl, Dzieje książki, Warszawa 1965, s. 58. 